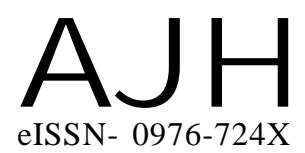

Received : 03.04.2014

Revised : 30.09 .2014

Accepted : 16.10.2014

\title{
Studies on preparation of aonla based blended RTS and squash from different fruits using stevia for low calorie
}

Members of the Research Forum

Associated Authors:

${ }^{1}$ Department of Post Harvest

Technology, College of Horticulture,

N.D. University of Agriculture and

Technology, Kumargunj, FAIZABAD

(U.P.) INDIA

Author for correspondence

OM SINGH

Department of Post Harvest Technology,

K.N.K. College of Horticulture,

MANDSAUR (M.P.) INDIA

Email : omsingh1921@gmail.com

\section{OM SINGH, RICHA SINGH ${ }^{1}$ AND PRATIKSHA SINGH ${ }^{1}$}

ABSTRACT : The present investigation was carried out in the Department of Post Harvest Technology, N.D. University of Agriculture and Technology, Kumargunj, Faizabad (U.P.) during 2010-2011, with the objective to develop aonla based low calorie blended RTS and squash from aonla, mango, guava, jamun and jackfruit using stevia for low calorie. A blends containing 25 per cent aonla pulp +75 per cent mango pulp was found better for the preparation of RTS and squash both. In the preparation of low calorie RTS and squash half amount of the sugar can be successfully substituted by stevia without impairing the quality of beverage.

KEY WORDS : Blending ratio, Low calorie, RTS, Squash beverages

HOW TO CITE THIS ARTICLE : Singh, Om, Singh, Richa and Singh, Pratiksha (2014). Studies on preparation of aonla based blended RTS and squash from different fruits using stevia for low calorie. Asian J. Hort., 9(2) : 328-333. 